\title{
The utilization of gelled maize starch in the small intestine of sheep
}

\author{
BY R. W. MAYES* AND E. R. ØRSKOV \\ The Rowett Research Institute, Bucksburn, Aberdeen AB2 $9 S B$ \\ (Received 28 August I973-Accepted I4 Fanuary 1974)
}

\begin{abstract}
1. A solution of gelled maize starch and Cr-EDTA was continuously infused for 4 weeks via the abomasum into sheep of different ages. The proportions of infused $\alpha$-glucoside passing the terminal ileum as glucan (ethanol-precipitable $\alpha$-glucoside), dextrins (ethanolsoluble glucose polymers) and glucose, and the glucan and over-all $\alpha$-glucoside disappearances in the small intestine were determined. Ethanol-soluble $\alpha$-glucoside compounds in ileal digesta were further separated by paper chromatography.

2. Glucan was efficiently degraded, since little reached the terminal ileum. Most of the $\alpha$-glucoside in ileal digesta consisted of glucose and dextrins (mainly short chain length oligosaccharides), suggesting that $\alpha$-amylase activity was not limiting over-all starch utilization.

3. No adaptation of intestinal starch utilization was evident except that the proportion of infused $\alpha$-glucoside passing the terminal ileum as glucose decreased with time.

4. A negative correlation existed between the $\mathrm{pH}$ and the total $\alpha$-glucoside content of the ileal digesta, possibly relating to changes in the microbial activity.

5. The advantages and disadvantages of feeding with starch so as to by-pass rumen fermentation are discussed.
\end{abstract}

The use of cereal-based diets for ruminants is increasing with intensification of animal production systems. Starch is fermented in the rumen with consequent energy losses as methane and as heat. Such losses could be prevented by enabling the starch to be digested in the small intestine by the action of pancreatic $\alpha$-amylase $\left(E C_{3.2 .1}\right.$. I), mucosal $\alpha$-glucosidase ( $E C$ 3.2.1.20) and oligo-I,6-glucosidase ( $E C$ 3.2.1.10). A further increase in the efficiency over ruminal fermentation is also likely since the glucose formed is, after absorption, apparently metabolized more efficiently than the volatile fatty acids (Armstrong \& Blaxter, I957; Armstrong, Blaxter \& Graham, 1960). A simple method of avoiding rumen fermentation by exploitation of the oesophageal groove closure reflex has been developed (Ørskov \& Benzie, r 969 ). The possible increase in efficiency of energy utilization by ruminants by feeding starch in this way would depend upon the capacity of the small intestine to digest $\alpha$-linked glucose polymers.

Starch has been shown to be utilized in the small intestine of the ruminant (see Armstrong \& Beever, 1969; Ørskov, 1969) but probably to a limited extent. Little, Mitchell \& Reitnour (Ig68), using steers, found the disappearance from the small intestine to vary between 42 and $60 \%$ depending upon the quantity of starch administered via the abomasum. Pancreatic $\alpha$-amylase activity (Walker, 1959) and maltase activity (Hembry, Bell \& Hall, 1967) have been found to be lower in the ruminant than those activities generally found in simple-stomached animals. Glucose also has

\footnotetext{
* Present address: Department of Agricultural Chemistry, Queen's University, Newforge Lane, Belfast BT9 5 PX.
} 
been shown to be absorbed less efficiently from the sheep than from the rat small intestine (White, Williams \& Morris, 197I).

The activity of digestive enzymes may increase in the long-term due to the presence of the relevant substrate in the small intestine. Such adaptation has been reported to occur in ruminants with pancreatic amylase in response to starch (Clary, Mitchell \& Little, I967; Clary, Mitchell, Little \& Bradley, 1969), and in rats with maltase in response to dietary maltose (Reddy, Pleasants \& Wostmann, 1968). White et al. (1971) have provided evidence that the efficiency of glucose absorption may similarly adapt.

Limitation and adaptation could occur at any of the stages in intestinal starch utilization. In the work described here we have estimated the quantities of starch degradation products appearing at the terminal ileum when gelled maize starch was continuously infused for 4 weeks via the abomasum using sheep of various ages. From the results we have attempted to show where in the process of starch utilization, limitation and adaptation might occur.

A preliminary account of this work has been published (Mayes \& Ørskov, I972).

\section{EXPERIMENTAL}

\section{Animals}

Two female lambs and two mature female sheep were used. The lambs were removed from the dam within I week of birth and were trained to drink from a bottle. They were also given free access to chopped dried grass and to drinking-water. At about 2 weeks of age each lamb was fitted with a simple cannula in the ileum about $150 \mathrm{~mm}$ from the ileo-caecal valve, and a $2 \mathrm{~mm}$ bore polyethylene catheter opening into the fundic region of the abomasum. After surgery the lambs rapidly recovered and at about 4 weeks of age were weaned from the bottle. The two mature sheep, which were aged between 2 and 3 years, had been fitted with simple cannulas in the abomasum and the terminal ileum, as described by Ørskov, Fraser \& Kay (1969).

\section{Management of animals, infusion and sampling procedure}

Starch infusion via the abomasum was carried out over 4-week periods starting when the lambs were 5 weeks of age and repeated when they were 13 weeks of age. From 4 to 17 weeks of age they were offered chopped dried grass ad lib. and were weighed at weekly intervals.

The mature sheep were given chopped dried grass ad lib. throughout, from I week before the beginning of the infusion period. The dried grass offered to all animals contained $146 \mathrm{~g}$ crude protein $(N \times 6 \cdot 25) / \mathrm{kg}$ and $53 \mathrm{~g}$ ash $/ \mathrm{kg}$ in the dry matter.

About $36 \mathrm{~h}$ before commencing the starch infusion, the animals were placed in metabolism cages and saline solution $(8 \cdot 5 \mathrm{~g} \mathrm{NaCl} / 1)$ was infused into the abomasum by means of a peristaltic pump (Watson-Marlow, Falmouth, Cornwall) through the abomasal catheter or cannula. At I8.30 hours on the following day starch infusion began. The infusate contained $70 \mathrm{~g}$ gelled maize starch ('Amijel': Corn Products Ltd, Manchester)/l saline solution. The water-soluble indigestible marker $\mathrm{Cr}^{3+}$ EDTA, prepared by the method of Binnerts, van't Klooster \& Frens (1968), was also 
Table I. Details of sheep, intake of dried grass, duration of infusion period, infusion rates of total $\alpha$-glucoside and number of sampling days in each period

\begin{tabular}{|c|c|c|c|c|c|c|}
\hline Animal & Age & $\begin{array}{c}\text { Live weight (w) } \\
(\mathrm{kg})\end{array}$ & $\begin{array}{c}\text { Mean } \\
\text { intake of } \\
\text { dried grass } \\
\text { (g dry } \\
\text { matter } / \mathrm{d})\end{array}$ & $\begin{array}{c}\text { Daily } \\
\text { infusion } \\
\text { rate of } \\
\text { total } \\
\alpha \text {-glucoside } \\
\left(\mathrm{g} / \mathrm{kg} W^{0 \cdot 75}\right)\end{array}$ & $\begin{array}{l}\text { Duration } \\
\text { of } \\
\text { infusion } \\
\text { period } \\
\text { (d) }\end{array}$ & $\begin{array}{l}\text { Number } \\
\text { of } \\
\text { sampling } \\
\text { days }\end{array}$ \\
\hline$A$ & $5^{-9}$ weeks & $14.5(13.2-15.9)^{*}$ & 368 & $27 \cdot I$ & 28 & 9 \\
\hline$B$ & $5-9$ weeks & $1 \mathrm{I} \cdot 2(9 \cdot 5-12 \cdot 8)$ & 298 & $25 \cdot 8$ & 28 & 7 \\
\hline$A$ & I3-17 weeks & $22 \cdot 1\left(18 \cdot 5^{-25} 7\right)$ & 636 & $2 I \cdot 9$ & 27 & 8 \\
\hline$B$ & I3-17 weeks & $17.2(14.8-19.5)$ & 497 & $20 \cdot 6$ & 27 & 8 \\
\hline$C$ & $2-3$ years & $55^{\circ} \circ\left(55^{\circ} \circ-55^{\circ} \circ\right)$ & 645 & $14 \cdot 8$ & 27 & 7 \\
\hline$D$ & $2-3$ years & $57 \cdot \circ(57 \cdot 0-62 \cdot 5)$ & 860 & $14 \cdot 2$ & 27 & 8 \\
\hline
\end{tabular}

included in the infusate $(0.7 \mathrm{~g}$ chromium sesquioxide/1). To prevent the infusate setting to a gel prior to infusion, the solution was maintained at $50^{\circ}$. Infusion was continued for 27 or $28 \mathrm{~d}$. At 18.30 hours each day the amount of infusate which had not been infused was recorded and replaced by fresh solution. The infusion rate was set at a level such that the faeces were soft though remaining in pellet form, indicating that measurable quantities of $\alpha$-linked glucose polymers were passing the terminal ileum causing an intensive caecal fermentation. For the lambs at both ages the infusion rate was increased throughout the period in proportion to the live weight $(W)$ raised to the power 0.75 . The infusion rate for the mature sheep was maintained at a constant level throughout.

Sampling of ileal digesta was carried out on the day before starch infusion began, the first day of infusion, and thereafter at approximately $3 \mathrm{~d}$ intervals. As a result of occasional blockages and problems with the peristaltic pump, sampling days sometimes had to be changed, and in a few instances were omitted. Each digesta sample was a composite of five collections taken at I0.00, 12.00, I4.00, I6.00 and I8.00 hours on the sampling day. Details of animals, intake of dried grass, duration and rates of infusion and sampling days of the infusion periods are shown in Table I. On several occasions no digesta was flowing through the cannula at the time of sampling. In such instances a small plastic bag was fitted over the open cannula until digesta was passing. It was difficult to keep the sample size constant owing to fluctuations in the flow of digesta through the small intestine, but about $\times 50 \mathrm{ml}$ of fluid was obtained each sampling day. Between collections and before $\mathrm{pH}$ determinations, samples were stored in sealed vessels at $-20^{\circ}$. Samples were allowed to thaw at $4^{\circ}$ overnight before the $\mathrm{pH}$ was determined using a glass electrode. Immediately afterwards the samples were freezedried for subsequent analysis.

During the final $2 \mathrm{~d}$ of infusion, the urine output of each animal was determined. A composite sample of urine, uncontaminated by faeces, was also obtained from collection at five 2 -hourly intervals during the final day. This sample was stored at $-20^{\circ}$ until analysed for chromium. 


\section{Estimation of starch degradation products}

The enzymic method of MacRae \& Armstrong ( 1968 ) determines both $\alpha$-linked glucose polymers and unpolymerized glucose. Modifications of this method enabled fractionation of the $\alpha$-glucoside in ileal digesta into glucan ( $S$, long-chain polymers, precipitated by hot ethanol), dextrins ( $D$, shorter-chain polymers, soluble in hot ethanol) and unpolymerized glucose $(G)$. Fractionation was achieved by estimating the total $\alpha$-glucoside $(T=S+D+G)$, the ethanol-soluble $\alpha$-glucoside fraction $(E=D+G)$, and glucose $(G)$. Then:

and

$$
\begin{aligned}
& \text { glucan }=T-E, \\
& \text { dextrins }=E-G, \\
& \text { glucose }=G .
\end{aligned}
$$

In order that such calculations could be made, all fractions had to be expressed in terms of glucose equivalent, which is the equivalent amount of glucose formed from the fraction upon its hydrolysis.

Total $\alpha$-glucoside was estimated by the method of MacRae \& Armstrong (I968) with the modification that the $\alpha$-amyloglucosidase (Agidex: Glaxo Laboratories Ltd, Greenford, Middlesex) was added as a filtered solution (2.5 g/l in acetate buffer, $\mathrm{pH}_{4} \cdot 5$ ). Also, after hydrolysis, the suspension was decolorized by the addition of $0.1 \mathrm{~g}$ charcoal (activated decolorizing powder, BDH Chemicals Ltd, Poole, Dorset). After centrifugation, glucose was determined by the glucose oxidase method.

The ethanol-soluble $\alpha$-glucoside fraction was also determined enzymically. To $0.3 \mathrm{~g}$ of freeze-dried digesta, $5 \mathrm{ml}$ of water was added, followed by $25 \mathrm{ml}$ of hot $\left(60^{\circ}\right)$ ethanol and $0.3 \mathrm{~g}$ charcoal. The mixture was shaken, sealed and allowed to stand for $18 \mathrm{~h}$. After centrifugation $15 \mathrm{ml}$ of the supernatant fluid was reduced in volume by evaporation to $2-3 \mathrm{ml}$ and then made up to $100 \mathrm{ml}$ with distilled-water. A $2 \mathrm{ml}$ portion of this solution was incubated for $12 \mathrm{~h}$ at $60^{\circ}$ with $6 \mathrm{ml}$ of $\alpha$-amyloglucosidase solution (see above) under a layer of light liquid paraffin. The glucose present after hydrolysis was determined by the glucose oxidase method. It was necessary in this estimation to correct for the contraction in volume occurring when hot ethanol was added to the water suspension. Using mixed alcoholic solutions of maltose and glucose, and of partially hydrolysed maize starch, it was found that the charcoal used in the above analyses did not remove any sugar from solution under the same analytical conditions.

The glucose content of digesta was determined by the glucose oxidase method after decolorization of a water suspension with charcoal and subsequent centrifugation. To inactivate any disaccharidases present in the glucose oxidase preparation, tris buffer was used (Dahlqvist, 1964).

The glucan, dextrins and glucose contents of the gelled maize starch present in the infusate were also estimated and were respectively as follows ( $\mathrm{g} / \mathrm{kg}$ dry matter): 1070, I7, 0 .

In an attempt to identify and determine the $\alpha$-linked glucose compounds present in the ethanol-soluble fraction from digesta, samples taken on the initial and final days of 
starch infusion were subjected to ascending-phase paper chromatography. Approximately $10 \mathrm{mg}$ of sugars was applied to each chromatogram as an ethanolic extract of the digesta. Two concurrent chromatograms from each sample were twice developed using $n$-butanol-ethanol-water (2:I:I, by vol.) as the solvent (Whistler \& Hickson, 1955); each development lasted $36 \mathrm{~h}$. The sugar spots were made visible by spraying one of the chromatograms with aniline phthalate solution ( $0.1 \mathrm{M}$ in water, saturated with $n$-butanol). The other chromatogram was cut into transverse strips, such that each contained a sugar spot. The $\alpha$-linked glucose present in each strip was determined by incubation for $18 \mathrm{~h}$ at $60^{\circ}$ with $5 \mathrm{ml}$ filtered $\alpha$-amyloglucosidase solution. The glucose released upon hydrolysis was estimated by the glucose oxidase method.

\section{Cr Analysis}

$\mathrm{Cr}$ EDTA in the infusate, digesta and urine was estimated as $\mathrm{Cr}_{2} \mathrm{O}_{3}$. The $\mathrm{Cr}$ concentration in the ashed samples was determined in a Technicon AutoAnalyzer using a modification of the method of Stevenson \& Clare (1963) described by Mathieson (1970).

Calculation of recoveries of starch degradation products at the terminal ileum and their disappearance from the small intestine

The proportions of infused total $\alpha$-glucoside passing the terminal ileum as glucan, dextrins and glucose were calculated by reference to the $\mathrm{Cr}$ contents of the infusate and ileal digesta. A correction was made for incomplete recovery of the marker, assuming its urinary excretion (about $3 \%$ of infused Cr EDTA) to represent absorption from the small intestine. In all instances the $\alpha$-glucoside content of the digesta when no starch was infused was too low to be determined accurately (less than $0.8 \%$ in the digesta dry matter) and this was ignored in the calculation of the proportions of infused $\alpha$-glucoside passing the terminal ileum.

\section{RESULTS}

$\alpha$-Linked glucose compounds passing the terminal ileum and their disappearance from the small intestine

The possibility of adaptation was assessed by comparing the means of the proportions of infused total $\alpha$-glucoside passing the terminal ileum as glucan, dextrins and glucose during the initial so $\mathrm{d}$ and during the last ro $\mathrm{d}$ of the infusion periods. These results are shown in Table 2 . It can be seen that there was no evidence of any adaptation except, apparently, for the proportion recovered as glucose which, in all instances, was lower in the final ro $\mathrm{d}$ than in the initial ro $\mathrm{d}$ of the infusion period.

The mean proportions of glucoside fractions passing the terminal ileum and disappearing from the small intestine over the entire infusion periods are presented in Table 3. In all instances most of the $\alpha$-glucoside passing the terminal ileum consisted of dextrins. Glucan was apparently digested very efficiently; the relatively low over-all $\alpha$-glucoside disappearance was thus evidently due to the poor utilization of dextrins and glucose. 
Table 2. Mean proportions of infused total $\alpha$-glucoside passing the terminal ileum 'of sheep as glucose, dextrins, glucan and total $\alpha$-glucoside over the initial 1od and final ro $d$ within each infusion period

(Each value is a mean of three or four observations)

\begin{tabular}{|c|c|c|c|c|c|c|}
\hline \multirow[b]{2}{*}{ Animal } & \multirow[b]{2}{*}{ Age } & & \multicolumn{4}{|c|}{$\begin{array}{l}\text { Proportion of infused } \alpha \text {-glucoside }(\mathrm{g} / \mathrm{kg} \text { ) } \\
\text { passing terminal ileum as }\end{array}$} \\
\hline & & & Glucose & Dextrins & Glucan & Total \\
\hline \multirow[t]{2}{*}{$A$} & $5-9$ weeks & $\begin{array}{l}\text { First ro d } \\
\text { Final ro d }\end{array}$ & $\begin{array}{l}37 \\
20\end{array}$ & $\begin{array}{l}264 \\
347\end{array}$ & $\begin{array}{l}78 \\
36\end{array}$ & $\begin{array}{l}379 \\
403\end{array}$ \\
\hline & & Difference & $-I 7$ & +83 & -42 & +24 \\
\hline \multirow[t]{2}{*}{$B$} & $5^{-9}$ weeks & $\begin{array}{l}\text { First ro d } \\
\text { Final Io d }\end{array}$ & $\begin{array}{l}48 \\
42\end{array}$ & $\begin{array}{l}354 \\
318\end{array}$ & $\begin{array}{l}125 \\
144\end{array}$ & $\begin{array}{l}527 \\
504\end{array}$ \\
\hline & & Difference & -6 & $-3^{6}$ & +19 & -23 \\
\hline \multirow[t]{2}{*}{$A$} & $13-17$ weeks & $\begin{array}{l}\text { First rod } \\
\text { Final ro d }\end{array}$ & $\begin{array}{l}90 \\
50\end{array}$ & $\begin{array}{l}265 \\
258\end{array}$ & $\begin{array}{r}75 \\
159\end{array}$ & $\begin{array}{l}43 \circ \\
467\end{array}$ \\
\hline & & Difference & -40 & -7 & +84 & +37 \\
\hline \multirow[t]{2}{*}{$B$} & I $3-x 7$ weeks & $\begin{array}{l}\text { First 1o d } \\
\text { Final 1o d }\end{array}$ & $\begin{array}{l}57 \\
52\end{array}$ & $\begin{array}{l}285 \\
257\end{array}$ & $\begin{array}{l}130 \\
164\end{array}$ & $\begin{array}{l}472 \\
473\end{array}$ \\
\hline & & Difference & -5 & -28 & +34 & +1 \\
\hline \multirow[t]{2}{*}{$C$} & $2-3$ years & $\begin{array}{l}\text { First rod } \\
\text { Final rod }\end{array}$ & $\begin{array}{l}95 \\
50\end{array}$ & $\begin{array}{l}140 \\
248\end{array}$ & $\begin{array}{l}40 \\
14\end{array}$ & $\begin{array}{l}275 \\
312\end{array}$ \\
\hline & & Difference & -45 & +108 & -26 & +37 \\
\hline \multirow[t]{2}{*}{$D$} & $2-3$ years & $\begin{array}{l}\text { First 10 d } \\
\text { Final ro d }\end{array}$ & $\begin{array}{l}67 \\
55\end{array}$ & $\begin{array}{l}304 \\
285\end{array}$ & $\begin{array}{r}4 \\
13\end{array}$ & $\begin{array}{l}375 \\
353\end{array}$ \\
\hline & & Difference & -12 & -19 & +9 & -22 \\
\hline
\end{tabular}

Table 3. Mean proportions of infused total $\alpha$-glucoside passing the terminal ileum of sheep as glucose, dextrins and glucan and the disappearance of $\alpha$-glucosides from the small intestine throughout the infusion period

\begin{tabular}{|c|c|c|c|c|c|c|c|c|c|c|c|}
\hline \multirow[b]{4}{*}{ Animal } & \multirow[b]{4}{*}{ Age } & \multirow{2}{*}{\multicolumn{6}{|c|}{$\begin{array}{c}\alpha \text {-Glucoside passing terminal ileum } \\
(\mathrm{g} / \mathrm{kg} \text { infused }) \text { as }\end{array}$}} & \multicolumn{3}{|c|}{$\begin{array}{l}\text { Apparent disappearance } \\
\text { in small intestine as }\end{array}$} & \multirow{4}{*}{$\begin{array}{l}\text { Daily dis- } \\
\text { appearance } \\
\text { of over-all } \\
\alpha \text {-glucoside } \\
\text { in small } \\
\text { intestine } \\
\left(\mathrm{g} / \mathrm{kg} W^{0 \cdot 75}\right)\end{array}$} \\
\hline & & & & & & & & & & Over-all & \\
\hline & & \multicolumn{2}{|c|}{ Glucose } & \multicolumn{2}{|c|}{ Dextrins } & \multicolumn{2}{|c|}{ Glucan } & \multicolumn{2}{|c|}{ ( $\mathrm{g} / \mathrm{kg}$ infused) } & \multirow{2}{*}{$\begin{array}{l}(\mathrm{g} / \mathrm{kg} \\
\text { infused }) \\
\text { Mean }\end{array}$} & \\
\hline & & Mean & SD & Mean & SD & Mean & SD & Mean & SD & & \\
\hline$A$ & 5-9 weeks & 45 & I & 323 & 7 & 59 & 8 & 940 & 9 & 573 & $15 \cdot 4$ \\
\hline$B$ & $5 \rightarrow 9$ weeks & 52 & 2 & $35^{\circ}$ & 2 & 141 & $\mathbf{I}$ & 857 & 3 & 457 & $12 \cdot 9$ \\
\hline$A$ & $1_{3}-1_{7}$ weeks & 69 & 3 & 259 & 2 & 112 & 4 & 892 & 6 & 560 & $12 \cdot 2$ \\
\hline$B$ & I3-I7 weeks & 58 & I & 257 & 3 & 146 & 4 & 852 & 4 & 539 & II'O \\
\hline$C$ & $2-3$ years & 74 & 2 & 19I & 7 & 32 & I I & 967 & I I & 703 & $9 \cdot 9$ \\
\hline$D$ & $2-3$ years & 63 & $\mathbf{I}$ & 306 & 3 & 2 & I & 998 & 3 & 629 & $9 \cdot 2$ \\
\hline
\end{tabular}


Table 4. Distribution of glucoside fractions in the total $\alpha$-glucoside of ileal digesta removed from each animal on the initial and final days of starch infusion

\begin{tabular}{|c|c|c|c|c|c|c|c|c|c|}
\hline \multirow[b]{2}{*}{ Animal } & \multirow[b]{2}{*}{ Age } & & \multicolumn{6}{|c|}{ Fraction in total $\alpha$-glucoside ( $/ \mathrm{kg}$ ) } & \multirow{2}{*}{$\begin{array}{c}\text { Total } \\
\alpha \text {-gluco- } \\
\text { side in } \\
\text { ileal dry } \\
\text { matter } \\
(\mathrm{g} / \mathrm{kg})\end{array}$} \\
\hline & & & Glucose & Maltose & $\begin{array}{c}\text { Malto- } \\
\text { triose }\end{array}$ & $\begin{array}{l}\text { Malto- } \\
\text { tetrose }\end{array}$ & $\begin{array}{l}\text { Higher } \\
\text { oligo- } \\
\text { saccharides }\end{array}$ & Glucan & \\
\hline$A$ & 5-9 weeks & $\begin{array}{l}\text { I } \\
\text { F }\end{array}$ & $\begin{array}{r}136 \\
93\end{array}$ & $\begin{array}{l}231 \\
218\end{array}$ & $\begin{array}{l}160 \\
215\end{array}$ & $\begin{array}{l}136 \\
194\end{array}$ & $\begin{array}{r}83 \\
280\end{array}$ & $\begin{array}{r}254 \\
0\end{array}$ & $\begin{array}{l}203 \\
245\end{array}$ \\
\hline$B$ & 5-9 weeks & $\begin{array}{l}\text { I } \\
\text { F }\end{array}$ & $\begin{array}{l}83 \\
70\end{array}$ & $\begin{array}{l}133 \\
183\end{array}$ & $\begin{array}{l}182 \\
165\end{array}$ & $\begin{array}{l}198 \\
179\end{array}$ & $\begin{array}{l}\text { I3I } \\
\text { I39 }\end{array}$ & $\begin{array}{l}273 \\
264\end{array}$ & $\begin{array}{l}175 \\
372\end{array}$ \\
\hline$A$ & 13-17 weeks & $\begin{array}{l}\text { I } \\
\text { F }\end{array}$ & $\begin{array}{l}133 \\
109\end{array}$ & $\begin{array}{l}165 \\
171\end{array}$ & $\begin{array}{l}\text { I39 } \\
\text { I53 }\end{array}$ & $\begin{array}{l}\text { r } 37 \\
141\end{array}$ & $\begin{array}{r}320 \\
77\end{array}$ & $\begin{array}{l}106 \\
349\end{array}$ & $\begin{array}{l}155 \\
268\end{array}$ \\
\hline$B$ & 13-17 weeks & $\begin{array}{l}\text { I } \\
\text { F }\end{array}$ & $\begin{array}{r}171 \\
71\end{array}$ & $\begin{array}{l}168 \\
124\end{array}$ & $\begin{array}{l}\text { I3 } 1 \\
\text { I53 }\end{array}$ & $\begin{array}{l}140 \\
156\end{array}$ & $\begin{array}{r}159 \\
168\end{array}$ & $\begin{array}{l}23 I \\
328\end{array}$ & $\begin{array}{l}204 \\
323\end{array}$ \\
\hline$C$ & $2-3$ years & $\begin{array}{l}\text { I } \\
\text { F }\end{array}$ & $\begin{array}{l}207 \\
110\end{array}$ & $\begin{array}{l}176 \\
\text { I } 54\end{array}$ & $\begin{array}{l}150 \\
151\end{array}$ & $\begin{array}{l}\mathbf{1} 47 \\
252\end{array}$ & $\begin{array}{l}114 \\
200\end{array}$ & $\begin{array}{l}206 \\
133\end{array}$ & $\begin{array}{l}364 \\
193\end{array}$ \\
\hline$D$ & $2-3$ years & $\begin{array}{l}\mathrm{I} \\
\mathrm{F}\end{array}$ & $\begin{array}{l}169 \\
136\end{array}$ & $\begin{array}{l}168 \\
214\end{array}$ & $\begin{array}{l}195 \\
234\end{array}$ & $\begin{array}{l}286 \\
269\end{array}$ & $\begin{array}{l}182 \\
105\end{array}$ & $\begin{array}{r}\circ \\
42\end{array}$ & $\begin{array}{l}102 \\
133\end{array}$ \\
\hline & General mean & & 121 & 174 & I68 & 183 & 157 & 197 & 223 \\
\hline
\end{tabular}

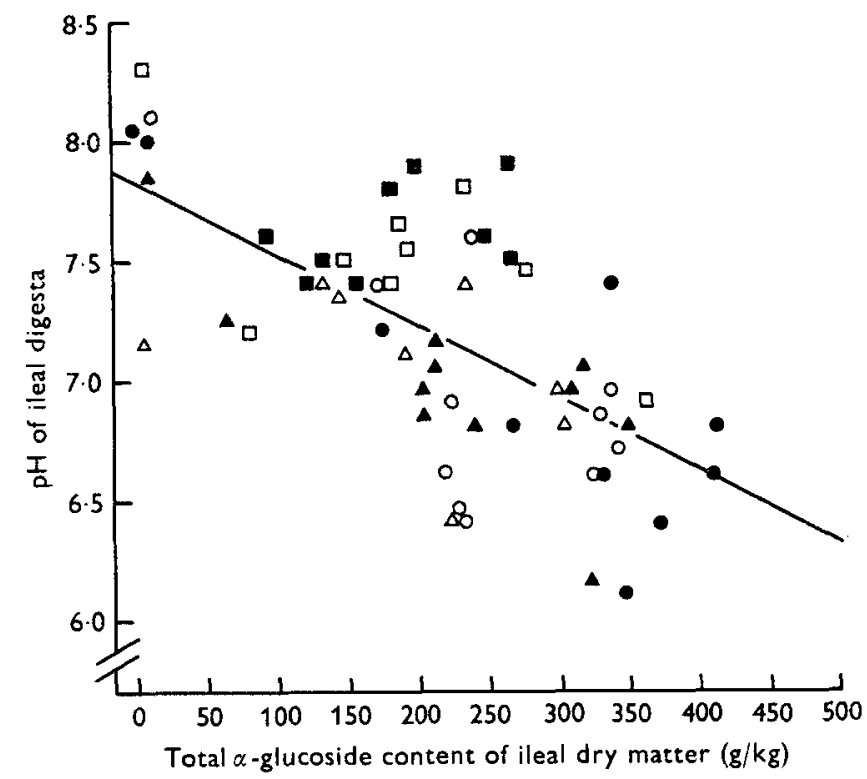

Fig. $\mathrm{x}$. The relationship between the $\mathrm{pH}$ and the total $\alpha$-glucoside content of ileal digesta removed from lambs $A(O)$ and $B(\bullet)$ aged 5-9 weeks, lambs $A(\triangle)$ and $B(\Delta)$ aged 13-17 $^{-1}$ weeks and sheep $C(\square)$ and $D(\square)$ aged 2-3 years. 


\section{Characterization of the $\alpha$-glucosides in ileal digesta}

Paper chromatography of ethanolic extracts of digesta samples taken on the initial and final days of each starch infusion period separated oligosaccharides of chain length up to four glucose units (maltotetrose). A further fraction remained stationary on the chromatograms and was assumed to consist of higher oligosaccharides. The distribution of the $\alpha$-glucoside fractions in the total $\alpha$-glucoside was calculated by including the glucan value, and the results are shown in Table 4 . Although there were large variations between infusion periods, in general, the total $\alpha$-glucoside was approximately equally distributed throughout the individual fractions, the majority consisting of short chain length oligosaccharides. The reduction in the proportion as free glucose between the initial and final days over all the periods was statistically significant $(P<0.05)$.

\section{$p H$ of the ileal digesta}

A regression of the digesta $\mathrm{pH}$ against the total $\alpha$-glucoside content of the digesta revealed a negative correlation $(r=0.66)$ with the equation:

$$
Y=7.87-0.003 \mathrm{I} X \quad \text { (residual sD 0.39;P< 0.00I). }
$$

As the total $\alpha$-glucoside content of the digesta $(X)$ increased there was a reduction in its $\mathrm{pH}(Y)$.

\section{DISCUSSION}

\section{Starch degradation within the small intestine and adaptation}

It is apparent from Table 3 that glucan was very readily degraded in the small intestine, probably by the action of $\alpha$-amylase. This enzyme is also responsible for most of the hydrolysis of glucan degradation products to glucose, maltose, maltotriose and $\alpha$-limit dextrins (oligosaccharides containing an $\alpha-\mathrm{r}, 6$ glucose linkage). It is thus important to know the relative quantities of individual $\alpha$-glucose compounds which were present in the digesta, before an assessment of degradation by $\alpha$-amylase could be made. The distribution in ileal digesta of individual $\alpha$-glucosides is a function of their rates of formation and rates of removal in the small intestine. About half the total $\alpha$-glucoside in the digesta consisted of glucose, maltose and maltotriose (Table 4 ). It would therefore appear that the major limitation was the utilization of these sugars, either in the hydrolysis of maltose and maltotriose by intestinal $\alpha$-glucosidase (maltase) or in the absorption of maltose and glucose into the brush border cells (see Mansford, I967). The stationary fraction present on each of the chromatograms, designated 'higher oligosaccharides', probably contained some $\alpha$-limit dextrins. Since these compounds are end-products of starch digestion by $\alpha$-amylase, their subsequent utilization would depend upon the level of intestinal oligo-r,6-glucosidase. The activity of this enzyme has not been determined in sheep but has been shown to be absent in calves (Capdeville, Frezal, Jos, Rey \& Lamy, 1967), so the importance of the $\alpha$-limit dextrins as a source of glucose is not known. Starch, apparently, was thus effectively digested by $\alpha$-amylase and the activity of this enzyme may not have been a factor limiting intestinal starch utilization. 
It is not possible to say whether the reduction in the proportion of total $\alpha$-glucosides as free glucose between the initial and final stages of the infusion period represented an adaptive increase in the efficiency of glucose absorption, particularly since no increase in the utilization of total $\alpha$-glucosides was observed. Day-to-day variations in infusion rate, and, with the lambs, the increase in infusion rate throughout the infusion period could have masked any small degree of adaptation in utilization that may have occurred.

The activity of microbes present in the small intestine may have an important role in intestinal starch utilization. Normally the microbial activity of the small intestine is low with an increase towards the distal end of the ileum. However, microbial utilization of starch is not necessarily negligible. Rumen bacteria possess $\alpha$-amylase activity (Hungate, 1966) and, if similar organisms were present in the small intestine, they would give similar $\alpha$-glucoside degradation products to those produced by pancreatic amylase activity. Furthermore, some $\alpha$-glucoside would no doubt be utilized as an energy source for the microflora, presumably with the production of volatile fatty acids. Thus intestinal disappearance of $\alpha$-linked glucose does not necessarily represent absorption as glucose or maltose. The extent of starch utilization by the microflora could not be assessed in this work. However, the relationship between the $\mathrm{pH}$ and total $\alpha$-glucoside content of the ileal digesta suggests that microbial activity increased as a result of starch infusion, since the reduction in $\mathrm{pH}$ could have arisen from increased volatile fatty acid concentrations. There is evidence that microflora may utilize carbohydrates in the small intestine. Ørskov, Mayes \& Mann (r972) found that the invertase activity of the small intestine was too low to account for sucrose disappearance, when this sugar was infused into the abomasum. Small quantities of cellulose may disappear from the small intestine (see Armstrong \& Beever, r969) although enzymes capable of cleaving the $\beta-1,4$ carbohydrate linkage are not produced by the host animal.

The gelled starch used in the work described here was chosen because it formed a stable colloidal solution which facilitated infusion. However, raw starches may be less efficiently digested. In unpublished work (E. R. Ørskov \& R. W. Mayes) it has been found, using mature sheep and abomasal infusion, that maize starch was digested more readily in the small intestine when gelled than when raw. Cooked (gelled) starch is also fermented more rapidly than raw starch by the rumen microflora, as shown with Streptococcus bovis (Hungate, 1966), and consequently more starch avoids rumen fermentation with feeding of uncooked maize (Ørskov et al. 1969). These differences in rates of breakdown are probably due to differences in the susceptibility to attack by amylase and so increases in the activity of this enzyme described by Clary et al. (1967) and Clary et al. (1969), who used raw starch, may benefit the animal. Since in this study $\alpha$-amylase was not apparently a limiting factor in the utilization of gelled maize starch, any increase in the activity of this enzyme would have had little if any effect. 


\section{Over-all utilization of gelled maize starch in the small intestine}

The results presented in Table 3 indicate that the over-all $\alpha$-glucoside utilization in the small intestine was between 45 and $70 \%$ of infused glucoside. If such disappearance is taken to represent absorption as glucose or maltose, the validity of which, as stated, is dependent upon microbial activity, considerable quantities of glucose would have been available for metabolism. Armstrong (1965) calculated the daily metabolic glucose requirement for the $55 \mathrm{~kg}$ non-pregnant sheep to be $4.4 \mathrm{~g} / \mathrm{kg} W^{0.75}$. The removal rates determined in this study were $2-3$ times this estimate of requirement, and, assuming that absorbed glucose was normally metabolized, represented about half the maintenance energy requirement according to Ørskov \& McDonald ( 1970 ).

Considerable quantities of $\alpha$-glucoside were, however, reaching the caecum. Starch fermentation in the large intestine has been shown to be very similar to rumen fermentation (Ørskov, Fraser, Mason \& Mann, 1970) but with the added disadvantages that the microbial protein produced is not effectively utilized, and that volatile fatty acid absorption is probably inefficient. Orskov et al. (1970), using mature sheep, found that about $15^{2} \mathrm{~g}$ of $\alpha$-glucoside in raw maize starch/d was capable of being fermented in the hind gut. In the mature sheep of the present study about ro $\mathrm{g}$ $\alpha$-glucoside/d passed into the caecum.

Further information on the quantitative importance of microbial utilization in the small intestine is required before it is possible to ascertain the merit of post-ruminal starch utilization. The effects of frequency of post-ruminal administration of starch also needs to be investigated. The results obtained here by continuous infusion may not be the same as intermittent administration.

We should like to thank Dr R. N. B. Kay for the surgical preparations and members of the Duthie Experimental Farm for their routine care of the animals.

\section{REFERENCES}

Armstrong, D. G. (1965). In Physiology of Digestion in the Ruminant p. 272 [R. W. Dougherty, editor]. London: Butterworths.

Armstrong, D. G. \& Beever, D. E. (1969). Proc. Nutr. Soc. 28, 121.

Armstrong, D. G. \& Blaxter, K. L. (1957). Br. F. Nutr. I1, 4 I 3.

Armstrong, D. G., Blaxter, K. L. \& Graham, N. McC. (1960). Proc. Nutr. Soc. 19, xxxi.

Binnerts, W. T., van't Klooster, A. T. \& Frens, A. M. (1968). Vet. Rec. 82, 470.

Capdeville, Y., Frezal, J., Jos, J., Rey, J. \& Lamy, M. (1967). C. r. hebd. Séanc. Acad. Sci., Paris, Ser. D 264, 519.

Clary, J. J., Mitchell, G. E. \& Little, C. O. (1967). Y. Anim. Sci. 26, 917.

Clary, J. J., Mitchell, G. E., Little, C. O. \& Bradley, N. W. (1969). Can. Y. Physiol. Pharmac. 47, I61.

Dahlquist, A. (1964). Analyt. Biochem. 7, 18.

Hembry, F. G., Bell, M. C. \& Hall, R. F. (1967). F. Nutr. 93, 175.

Hungate, R. E. (1966). The Rumen and its Microbes, p. 60. New York and London: Academic Press.

Little, C. O., Mitchell, G. E. \& Reitnour, C. M. (x968). F. Anim. Sci. 27, 790.

MacRae, J. C. \& Armstrong, D. G. (1968). F. Sci. Fd Agric. 19, 578.

Mansford, K. R. L. (1967). Proc. Nutr. Soc. 26, 27.

Mathieson, J. (1970). Proc. Nutr. Soc. 29, 30A.

Mayes, R. W. \& Orskov, E. R. (1972). Proc. Nutr. Soc. 31, 64 A.

Orskov, E. R. (1969). Revta cub. Cienc. agric. (English ed.) 3, 1. 
Ørskov, E. R. \& Benzie, D. (1969). Br. Y. Nutr. 23, 4I5.

Ørskov, E. R., Fraser, C. \& Kay, R. N. B. (1969). Br. 尹. Nutr. 23, 217.

Ørskov, E. R., Fraser, C., Mason, V. C. \& Mann, S. O. (1970). Br. F. Nutr. 24, 671 .

Ørskov, E. R. \& McDonald, I. (1970). In Energy Metabolism of Farm Animals p. 121 [A. Schurch and C. Wenk, editors]. Zurich: Jures Verlag.

Orskov, E. R., Mayes, R. W. \& Mann, S. O. (1972). Br. F. Nutr. $28,425$.

Reddy, B. S., Pleasants, J. R. \& Wostmann, B. S. (1968). F. Nutr. 95, 413.

Stevenson, A. E. \& Clare, N. T. (1963). N.Z. Yll agric. Res. 6, 121.

Walker, D. M. (1959). J. agric. Sci., Camb. 53, 374.

Whistler, R. L. \& Hickson, J. L. (1955). Analyt. Chem. 27, 1514.

White, R. G., Williams, V. J. \& Morris, R. J. H. (1971). Br. J. Nutr. 25, 57. 